Jurnal Ilmu Ilmu Agribisnis: Journal of Agribusiness Science, 9(1), Februari 2021

\title{
PENDAPATAN DAN RISIKO USAHATANI CABAI DI KECAMATAN SUMBEREJO KABUPATEN TANGGAMUS
}

\author{
(The Income and Risks of Chili Farming in Sumberejo Sub-District Tanggamus Regency)
}

Nurul Mala, Fembriarti Erry Prasmatiwi, Wuryaningsih Dwi Sayekti

Jurusan Agribisnis, Fakultas Pertanian, Universitas Lampung, Jl. Prof. Dr. Soemantri Brodjonegoro No. 1

Bandar Lampung 35145, e-mail: fembriarti.erry@fp.unila.ac.id

\begin{abstract}
This research aims to find out the comparison of income and the risk of chili pepper (Capsicum annum L.) farming and cayenne pepper (Capsicum Frutescens L.) farming. The study was conducted in three villages at Sumberejo Sub-district of Tanggamus Regency. This research used a survey method and respondents in this research were 30 chili pepper farmers and 30 cayenne pepper farmers. The data analysis used is farm income analysis and risk analysis uses coefficient of variation. To find out the comparison of income and risk of farming was independent sample t-test. The results showed that the income of chili pepper farming was higher than that of cayenne pepper farming with the income of IDR119,047,409.08 per hectare and IDR49,579,450.49 per hectare. There is no significant difference between production risk and income from chili pepper and cayenne pepper farming. The price risk of chili pepper farming is higher than that of cayenne pepper.
\end{abstract}

Key words: Chili farming, income, risk

\section{PENDAHULUAN}

Sektor pertanian merupakan salah satu sektor yang mempunyai peranan penting dalam meningkatkan perekonomian Indonesia. Salah satu subsektor pertanian yang memiliki laju pertumbuhan yang cukup tinggi terhadap Produk Domestik Bruto (PDB) adalah hortikultura. Hortikultura merupakan komoditas yang berpotensi untuk dikembangkan di masa yang akan datang, karena memiliki nilai ekonomis yang dapat mendorong pertumbuhan ekonomi dalam sektor pertanian, dimana laju pertumbuhan subsektor tanaman hortikultura pada tahun 2018 mencapai 6,99 persen (Badan Pusat Statistik 2019).

Cabai merupakan salah satu komoditas hortikultura yang dibutuhkan dan dikonsumsi oleh masyarakat Indonesia. Menurut Setiadi (2000), tanaman cabai yang dikenal di Indonesia, pada umumnya hanya dua kelompok besar yaitu cabai besar dan cabai kecil. Cabai besar dalam penelitian ini merupakan jenis cabai keriting, sedangkan cabai kecil (Capsicum frutescens $\mathrm{L}$.) sering mendapat sebutan cabai rawit. Selain berguna sebagai penyedap masakan, cabai juga mengandung zat-zat gizi yang sangat diperlukan untuk kesehatan manusia. Cabai mengandung protein, lemak, karbohidrat, kalsium, vitamin-vitamin, dan mengandung senyawasenyawa alkaloid, seperti capsaicin, flavonoid, dan minyak esensial (Prajnanta 2001).
Provinsi Lampung, merupakan salah satu provinsi yang memiliki potensi sumber daya lahan dan kesesuaian iklim untuk pengembangan usahatani cabai besar dan cabai rawit. Pada tahun 2014, luas panen cabai besar dan cabai rawit di Provinsi Lampung adalah 4.912 ha dan 2.583 ha. Tahun berikutnya yaitu pada tahun 2015 , luas panen cabai besar dan cabai rawit mengalami penurunan menjadi 4.229 ha dan 2.006 ha. Pada tahun 2016, luas panen cabai besar dan cabai rawit mengalami peningkatan sebesar 4.616 ha dan 2.024 ha. Perkembangan luas panen usahatani cabai besar dan cabai rawit yang berfluktuasi, dikarenakan adanya alih fungsi lahan yaitu sebagai lahan untuk usahatani cabai menjadi usahatani komoditas lainnya atau beralih fungsi lahan ke non pertanian (Dinas Pertanian Tanaman Pangan dan Hortikultura Provinsi Lampung 2017).

Salah satu daerah penghasil cabai besar dan cabai rawit di Provinsi Lampung adalah Kabupaten Tanggamus. Perkembangan luas panen cabai besar dan cabai rawit di Kabupaten Tanggamus pada tahun 2014 hingga tahun 2016 mengalami penurunan. Hal ini menyebabkan perkembangan produktivitas cabai besar dan cabai rawit di Kabupaten Tanggamus berfluktuasi. Pada tahun 2014, produktivitas tanaman cabai besar dan cabai rawit adalah 32,41 kuintal/ha dan 35,65 kuintal/ha, tahun 2015 produktivitas tanaman cabai besar meningkat sebesar 35,61 kuintal/ha dan pada tahun 
2016 produktivitas tanaman cabai besar kembali mengalami penurunan sebesar 30,66 kuintal/ha, sedangkan produktivitas tanaman cabai rawit pada tahun 2015 menurun sebesar 30,88 kuintal/ha, namun pada tahun 2016 mengalami peningkatan yang cukup tinggi yaitu 36,26 kuintal/ha (Dinas Pertanian Tanaman Pangan dan Hortikultura Provinsi Lampung 2017).

Tingkat harga yang tidak menentu (relatif tidak stabil) berpengaruh terhadap tingkat pendapatan yang diperoleh petani cabai. Perkembangan harga cabai besar dan cabai rawit di tingkat petani maupun di tingkat pengecer di Kabupaten Tanggamus tahun 2017 berfluktuasi di setiap bulan, dengan harga cabai besar dan cabai rawit tertinggi adalah sebesar Rp27.778,00/kg dan Rp51.500,00/kg di tingkat petani, selanjutnya sebesar Rp35.000,00/kg dan Rp61.500,00/kg di tingkat pengecer, sedangkan harga terendah yaitu sebesar Rp14.300,00/kg dan Rp14.989,00/kg di tingkat petani, kemudian sebesar Rp19.811,00/kg dan Rp17.417,00/kg di tingkat pengecer. Terjadinya fluktuasi harga cabai disebabkan oleh hasil produksi cabai yang tidak menentu dan waktu penjualan untuk mendapatkan harga yang lebih tinggi sulit terjadi, sehingga keinginan petani untuk memperoleh pendapatan yang tinggi juga sulit. (Dinas Pertanian Tanaman Pangan dan Hortikultura Provinsi Lampung 2017).

Kegiatan dalam usahatani yang menyangkut proses produksi selalu dihadapkan dengan situasi risiko. Risiko yang paling utama dihadapi petani cabai besar dan cabai rawit adalah risiko produksi yang disebabkan oleh faktor-faktor dalam kegiatan produksi seperti ketidakpastian cuaca serta serangan hama dan penyakit tanaman. Risiko harga terjadi karena adanya ketidakpastian harga jual cabai. Hal tesebut akan berdampak pada risiko tingkat pendapatan yang diperoleh petani.

Kabupaten Tanggamus terdiri dari 20 kecamatan. Diantara 20 kecamatan, yang berusahatani cabai besar dan cabai rawit adalah Kecamatan Sumberejo. Pada tahun 2016, Kecamatan Sumberejo memiliki luas panen 29 ha dan produksi 472 kuintal (BPS Kabupaten Tanggamus 2017). Selain itu, Kecamatan Sumberejo merupakan salah satu daerah yang menjadi sentra komoditas cabai yang didukung oleh keadaan tanah dan iklim yang baik untuk berusahatani cabai. Berdasarkan uraian tersebut, maka penelitian ini bertujuan untuk menganalisis perbandingan pendapatan dan risiko usahatani cabai besar dan cabai rawit di Kecamatan Sumberejo Kabupaten Tanggamus.

\section{METODE PENELITIAN}

Metode yang digunakan dalam penelitian ini adalah survei. Penelitian dilakukan di tiga pekon di Kecamatan Sumberejo Kabupaten Tanggamus yaitu Pekon Argopeni, Pekon Margodadi, dan Pekon Simpang Kanan. Penentuan lokasi penelitian dilakukan secara sengaja (purposive) dengan pertimbangan bahwa Kecamatan Sumberejo merupakan salah satu sentra produksi cabai dan salah satu kecamatan yang memilki kontribusi cukup tinggi terhadap produksi cabai di Kabupaten Tanggamus. Waktu pengumpulan data dilakukan pada bulan September-November 2018.

Populasi petani cabai besar dan cabai rawit di ketiga pekon yang ada di Kecamatan Sumberejo berjumlah 162 petani. Penentuan jumlah sampel petani cabai besar dan cabai rawit mengacu pada teori Gay dan Diehl (1992) yang menyatakan bila suatu penelitian merupakan penelitian kausal perbandingan maka sampel yang digunakan adalah 30 subyek per kelompok. Penelitian kausal perbandingan adalah perbandingan antara dua kelompok atau lebih dari suatu variabel tertentu (Arifin 2012). Berdasarkan penjelasan tersebut, maka jumlah sampel yang diambil dalam penelitian ini adalah 30 sampel untuk petani cabai besar dan 30 sampel untuk petani cabai rawit. Selanjutnya, jumlah sampel cabai besar dan cabai rawit dari tiap-tiap pekon ditentukan dengan rumus alokasi proporsional sample (Sugiarto et al. 2003):

$\mathrm{n}_{\mathrm{a}}=\frac{\mathrm{N}_{\mathrm{a}}}{\mathrm{N}_{\mathrm{ab}}} \cdot \mathrm{n}_{\mathrm{ab}}$

\section{Keterangan: \\ $\mathrm{n}_{\mathrm{a}} \quad=$ Jumlah sampel petani cabai \\ $\mathrm{n}_{\mathrm{ab}} \quad=$ Jumlah sampel keseluruhan \\ $\mathrm{N}_{\mathrm{a}} \quad$ = Jumlah populasi petani cabai \\ $\mathrm{N}_{\mathrm{ab}} \quad$ = Jumlah populasi keseluruhan}

Pengambilan sampel dilakukan secara acak sederhana dengan cara undian yang merupakan teknik sampel dengan mengundi setiap kelompok untuk dijadikan sampel (Arikunto 2006). Jenis data yang digunakan adalah data primer dan data sekunder. Data primer merupakan data yang dikumpulkan melalui wawancara secara langsung dengan petani menggunakan daftar pertanyaan (kuesioner) untuk mengetahui luas lahan, biaya produksi, proses produksi, harga dan risiko yang terjadi dalam usahatani cabai besar dan cabai rawit. Data sekunder diperoleh melalui instansi atau lembaga terkait seperti Dinas Pertanian Tanaman Pangan dan Hortikultura Provinsi Lampung (data 
luas panen, produktivitas dan harga usahatani cabai besar dan cabai rawit), Badan Pusat Statistik (data laju pertumbuhan sektor pertanian dan luas panen usahatani cabai di Kecamatan Sumberejo) dan Balai Penyuluh Pertanian Kecamatan Sumberejo Kabupaten Tanggamus (data jumlah petani cabai besar dan cabai rawit) serta data-data yang diperoleh dari laporan, publikasi dan pustaka lain yang berkaitan dengan penelitian.

Metode analisis data yang digunakan dalam penelitian adalah metode analisis kuantitatif untuk menganalisis pendapatan dan risiko usahatani cabai besar dan cabai rawit. Analisis data yang digunakan sama dengan penelitian Aini, Prasmatiwi dan Sayekti (2015) dan Saputra, Prasmatiwi dan Ismono (2017) yang menghitung analisis pendapatan usahatani dan risiko usahatani secara kuantitatif.

Pendapatan usahatani cabai besar dan cabai rawit diperoleh dengan menghitung selisih antara penerimaan dengan total biaya yang dikeluarkan pada usahatani cabai besar dan cabai rawit. Secara matematis, besarnya pendapatan dapat dirumuskan (Soekartawi 1995):

$$
\begin{aligned}
& \pi=\mathrm{TR}-\mathrm{TC} \\
& \pi=\mathrm{Y} . \mathrm{Py}-\sum_{\mathrm{i}=1}^{\mathrm{n}} \mathrm{Xi} . \text { Pxi }- \text { BTT } . \\
& \text { Keterangan : } \\
& \pi=\text { Pendapatan usahatani cabai besar dan } \\
& \text { cabai rawit (Rp) } \\
& \text { TR = Total penerimaan usahatani cabai besar } \\
& \text { dan cabai rawit }(\mathrm{Rp}) \\
& \mathrm{TC}=\text { Total biaya produksi }(\mathrm{Rp}) \\
& \mathrm{Y} \quad=\text { Jumlah produksi cabai }(\mathrm{Kg}) \\
& \text { Py } \quad=\text { Harga hasil produksi }(\mathrm{Rp} / \mathrm{kg}) \\
& \mathrm{Xi} \quad=\text { Faktor produksi variabel ke-i } \\
& \text { Pxi = Harga faktor produksi variabel ke-i } \\
& \text { (Rp/satuan) } \\
& \text { BTT = Biaya tetap total }(\mathrm{Rp})
\end{aligned}
$$

Untuk mengetahui apakah usahatani cabai besar dan cabai rawit menguntungkan atau tidak digunakan analisis Return Cost Ratio (R/C) dengan rumus (Soekartawi 1995):

$$
\mathrm{R} / \mathrm{C}=\frac{\mathrm{TR}}{\mathrm{TC}}
$$

\section{Keterangan :}

$\mathrm{R} / \mathrm{C}=$ Nisbah antara penerimaan dengan biaya

$\mathrm{TR}=$ Penerimaan total (total revenue) $(\mathrm{Rp})$

$\mathrm{TC}=$ Biaya total $($ total cost $)(\mathrm{Rp})$
Ada tiga kriteria dalam pengukurannya yaitu :

a. $\mathrm{R} / \mathrm{C}>1$, maka usahatani menguntungkan .

b. $\mathrm{R} / \mathrm{C}=1$, maka usahatani berada pada titik impas.

c. $\mathrm{R} / \mathrm{C}<1$, maka usahatani tidak menguntungkan.

Untuk mengetahui perbandingan pendapatan antara usahatani cabai besar dan cabai rawit, dilakukan uji beda independent sample t-test.

Tingkat risiko usahatani cabai besar dan cabai rawit, dihitung dengan menggunakan data produksi dan harga cabai pada lima musim tanam terakhir, setelah itu ditentukan berdasarkan nilai koefisien variasi (CV) (Pappas dan Hirschey 1995):

$\mathrm{CV}=\frac{\mathrm{V}}{\bar{\pi}}$

Keterangan :

$\mathrm{CV}=$ Koefisien variasi

$\mathrm{V}=$ Simpangan baku

$\bar{\pi} \quad=$ Rata-rata produksi, harga, dan pendapatan yang diharapkan

Nilai CV berbanding lurus dengan risiko yang dihadapi petani cabai besar dan cabai rawit, artinya semakin besar nilai CV yang didapat, maka semakin besar pula risiko yang harus ditanggung petani, begitu pula sebaliknya. Batas bawah (L) menunjukkan nilai terendah pendapatan yang mungkin diterima oleh petani. Apabila nilai batas bawah $(\mathrm{L})>0$, maka petani tidak akan mengalami kerugian (risiko kecil), sebaliknya jika nilai batas bawah (L) $<0$, maka petani akan mengalami kerugian (risiko tinggi) dan kerugian yang harus ditanggung petani adalah sebesar nilai L. Rumus perhitungan batas bawah adalah (Kadarsan 1995):

$\mathrm{L}=\bar{\pi}-2 \mathrm{~V}$

Keterangan :

$\mathrm{L}=$ Batas bawah

$\mathrm{V}=$ Standar deviasi (simpangan baku)

$\bar{\pi} \quad=$ Rata-rata pendapatan yang diharapkan

Untuk mengetahui perbandingan risiko produksi, harga, dan pendapatan antara usahatani cabai besar dan cabai rawit, dilakukan uji beda independent sample t-test.

\section{HASIL DAN PEMBAHASAN}

Hasil penelitian menunjukkan bahwa umur petani cabai besar dan petani cabai rawit mulai dari 38-60 tahun dengan rata-rata umur petani cabai besar dan cabai rawit yaitu 48 tahun dan 47 tahun. Mayoritas 
tingkat pendidikan petani cabai besar dan rawit adalah tingkat sekolah dasar (SD) yaitu sebesar 46,67 persen. Rata-rata jumlah tanggungan keluarga petani cabai besar $(60 \%)$ dan petani cabai rawit $(73,33 \%)$ berkisar antara tiga sampai empat orang. Petani cabai besar dan cabai rawit di daerah penelitian memiliki pengalaman berusahatani mulai dari 10-30 tahun dengan rata-rata petani cabai besar dan cabai rawit masing-masing selama 22,70 tahun dan 19,60 tahun.

Rata-rata luas lahan yang digunakan petani untuk berusahatani cabai besar adalah 0,36 ha, sedangkan rata-rata luas lahan yang digunakan petani untuk berusahatani cabai rawit adalah 0,31 ha, dengan status kepemilikan lahan petani cabai besar $(86,67 \%)$ dan petani cabai rawit $(83,33 \%)$ adalah milik sendiri, sedangkan sisanya adalah lahan sewa. Rata-rata harga sewa lahan usahatani cabai besar dan cabai rawit dalam satu kali musim tanam adalah Rp633.333/ha dan Rp1.277.777/ha. Sebanyak $(83,33 \%)$ petani cabai besar dan $(90 \%)$ petani cabai rawit menjadikan usahatani cabai sebagai satu-satunya sumber mata pencaharian dan jumlah petani yang memiliki pekerjaan sampingan hanya 16,67 persen dan 10 persen, yaitu sebagai pedagang dan buruh.

Usahatani cabai besar dan cabai rawit di daerah penelitian ditanam pada lahan sawah dengan pola tanam secara monokultur. Rata-rata penggunaan faktor produksi usahatani cabai besar dan cabai rawit disajikan pada Tabel 1. Faktor produksi yang digunakan petani cabai terdiri dari luas lahan, benih, pupuk, pestisida, dan tenaga kerja. Rata-rata penggunaan benih cabai besar dan cabai rawit adalah sama banyak yaitu $0,14 \mathrm{~kg} / \mathrm{ha}$. Rata-rata harga benih cabai besar adalah Rp128.000/pak dan rata-rata harga benih cabai rawit yaitu Rp31.000/pak, dengan berat bersih satu pak $10 \mathrm{~g}$.

Jenis pupuk yang banyak dipakai pada usahatani cabai besar dan cabai rawit adalah pupuk kandang sebanyak $1.203,70 \mathrm{~kg} / \mathrm{ha}$ dan $2.618,28 \mathrm{~kg} / \mathrm{ha}$,

Tabel 1. Rata-rata penerimaan, biaya, dan pendapatan usahatani cabai besar dan cabai rawit per hektar

\begin{tabular}{|c|c|c|c|c|c|c|c|}
\hline \multirow{2}{*}{ Uraian } & \multirow{2}{*}{ Satuan } & \multicolumn{3}{|c|}{ Usahatani cabai besar } & \multicolumn{3}{|c|}{ Usahatani cabai rawit } \\
\hline & & Jumlah & Harga (Rp) & Nilai (Rp) & Jumlah & Harga (Rp) & Nilai (Rp) \\
\hline \multicolumn{8}{|l|}{ Penerimaan } \\
\hline Produksi & $\mathrm{Kg}$ & $6.147,31$ & $27.916,67$ & $171.612 .538,58$ & $5.978,28$ & $19.316,67$ & $115.480 .433,69$ \\
\hline \multicolumn{8}{|l|}{ Biaya Produksi } \\
\hline \multicolumn{8}{|l|}{ 1.Biaya Tunai } \\
\hline Benih & $\mathrm{Kg}$ & 0,14 & $12.833 .333,33$ & $1.806 .172,84$ & 0,14 & $3.116 .666,67$ & $445.716,85$ \\
\hline Pupuk Za & $\mathrm{Kg}$ & 125,00 & $2.000,00$ & $250.000,00$ & 74,19 & $2.000,00$ & $148.387,10$ \\
\hline Pupuk NPK Phonska & $\mathrm{Kg}$ & 210,65 & $2.817,39$ & $593.478,26$ & 145,70 & $2.831,25$ & $412.510,08$ \\
\hline Pupuk SP36 & $\mathrm{Kg}$ & 37,04 & $2.987,50$ & $110.648,15$ & 47,31 & $2.962,50$ & $140.161,29$ \\
\hline Pupuk KCL & $\mathrm{Kg}$ & 34,72 & $6.430,00$ & $223.263,89$ & 63,44 & $6.263,64$ & $397.370,48$ \\
\hline Pupuk Urea & $\mathrm{Kg}$ & & & & 45,70 & $2.600,00$ & $118.817,20$ \\
\hline Pupuk NPK Basf & $\mathrm{Kg}$ & & & & 91,40 & $9.269,23$ & $847.187,76$ \\
\hline Pupuk TSP & $\mathrm{Kg}$ & & & & 40,32 & $9.142,86$ & $368.663,59$ \\
\hline Pupuk NPK Mutiara & $\mathrm{Kg}$ & 183,33 & $9.000,00$ & $1.650 .000,00$ & 100,54 & $9.150,00$ & $919.919,35$ \\
\hline Dolomit & $\mathrm{Kg}$ & & & & 639,78 & $1.000,00$ & $639.784,95$ \\
\hline Pupuk Kandang & $\mathrm{Kg}$ & $1.203,70$ & 500,00 & $601.851,85$ & $2.618,28$ & 500,00 & $1.309 .139,78$ \\
\hline Pestisida & $\mathrm{Rp}$ & & & $3.715 .185,19$ & & & $1.369 .569,89$ \\
\hline TK Luar Keluarga & $\mathrm{Rp}$ & & & $18.036 .111,11$ & & & $27.117 .204,30$ \\
\hline PBB & $\mathrm{Rp}$ & & & $61.944,44$ & & & $59.247,31$ \\
\hline Biaya Karung & $\mathrm{Rp}$ & & & $110.092,59$ & & & $173.655,91$ \\
\hline Sewa Lahan & $\mathrm{Rp}$ & & & $13.194,44$ & & & $41.218,64$ \\
\hline Total Biaya Tunai & $\mathrm{Rp}$ & & & $27.171 .942,77$ & & & $34.508 .554,49$ \\
\hline \multicolumn{8}{|l|}{ 2.Biaya Diperhitungkan } \\
\hline Sewa Lahan & $\mathrm{Rp}$ & & & $1.260 .416,67$ & & & $1.572 .580,65$ \\
\hline TK Dalam Keluarga & $\mathrm{Rp}$ & & & $20.469 .444,44$ & & & $26.522 .580,65$ \\
\hline Penyusutan Alat & $\mathrm{Rp}$ & & & $3.663 .325,62$ & & & $3.297 .177,42$ \\
\hline $\begin{array}{l}\text { Total Biaya } \\
\text { Diperhitugkan }\end{array}$ & $\mathrm{Rp}$ & & & $25.393 .186,73$ & & & $31.392 .338,71$ \\
\hline 3.Total Biaya & $\mathrm{Rp}$ & & & $52.565 .129,50$ & & & $65.900 .893,20$ \\
\hline \multicolumn{8}{|l|}{ Pendapatan } \\
\hline 1. Pendapatan Atas & & & & 144.440 .595 .81 & & & $80.971 .879,20$ \\
\hline Biaya Tunai & $\mathrm{Rp}$ & & & $144.440 .590,01$ & & & $00.911 .017,20$ \\
\hline $\begin{array}{l}\text { 2. Pendapatan Atas } \\
\text { Biaya Total }\end{array}$ & $\mathrm{Rp}$ & & & $119.047 .409,08$ & & & $49.579 .540,49$ \\
\hline \multicolumn{8}{|l|}{ R/C Rasio } \\
\hline 1. R/C Atas Biaya Tunai & $\mathrm{Rp}$ & & & 6,32 & & & 3,35 \\
\hline 2. R/C Atas Biaya Total & $\mathrm{Rp}$ & & & 3,26 & & & 1,75 \\
\hline
\end{tabular}


sedangkan penggunaan jenis pupuk yang lebih sedikit pada usahatani cabai besar dan cabai rawit yaitu pupuk $\mathrm{KCl}$ sebanyak $34,72 \mathrm{~kg} / \mathrm{ha}$ dan pupuk TSP sebanyak 40,32 kg/ha. Pada Tabel 1, terlihat bahwa secara keseluruhan penggunaan pupuk pada usahatani cabai rawit lebih banyak dari cabai besar. Hal ini dikarenakan tanaman cabai rawit merupakan tanaman yang berumur panjang. Usia tanaman cabai besar berkisar 6-7 bulan, sedangkan usia tanaman cabai rawit rata-rata 10 bulan.

Biaya produksi merupakan faktor produksi yang digunakan dikalikan dengan harga input. Berdasarkan Tabel 1, rata-rata biaya pestisida pada usahatani cabai besar adalah Rp3.715.185,19/ha, sedangkan rata-rata biaya pestisida pada usahatani cabai rawit yaitu Rp1.369.569,89/ha. Biaya yang dikeluarkan untuk penggunaan pestisida pada usahatani cabai besar lebih tinggi dari cabai rawit. Hal ini menunjukkan bahwa usahatani cabai besar lebih rentan terhadap serangan hama dan penyakit.

Tenaga kerja yang digunakan dalam berusahatani cabai dari pengolahan lahan hingga panen terdiri dari tenaga kerja dalam keluarga dan tenaga kerja luar keluarga. Rata-rata jumlah tenaga kerja pada usahatani cabai besar dan cabai rawit lebih banyak digunakan pada kegiatan panen, karena pada usahatani cabai pemanenan lebih dari satu kali yang mencapai 245,33 HKP dan 365,61 HKP.

\section{Produksi dan Pendapatan Usahatani Cabai}

Produksi merupakan hasil akhir dari proses atau kegiatan dalam usahatani dengan memanfaatkan faktor-faktor produksi yang tersedia. Rata-rata produksi usahatani cabai besar yang dihasilkan adalah sebanyak $6.147,31 \mathrm{~kg} / \mathrm{ha}$ dengan harga ratarata sebesar Rp27.916,67/kg dan penerimaan yang diterima oleh petani yaitu Rp171.612.538,58/ha. Rata-rata produksi usahatani cabai rawit adalah sebanyak 5.978,28 kg/ha dengan harga rata-rata Rp19.316,67/kg dan penerimaan yang diterima oleh petani yaitu sebesar Rp115.480.433,69/ha.

Biaya usahatani cabai besar dan cabai rawit terdiri dari biaya tunai dan biaya diperhitungkan. Berdasarkan Tabel 1, rata-rata total biaya usahatani cabai besar yang dikeluarkan petani adalah sebesar Rp52.565.129,50/ha, sedangkan rata-rata total biaya pada usahatani cabai rawit yaitu sebesar Rp65.900.893,20/ha. Total biaya yang dikeluarkan untuk berusahatani cabai rawit lebih besar dari usahatani cabai besar. Hal ini dikarenakan tanaman cabai rawit merupakan tanaman yang berumur lebih panjang dari cabai besar, sehingga faktor produksi seperti penggunaan pupuk dan jumlah tenaga kerja pada usahatani cabai rawit lebih banyak dibandingkan usahatani cabai besar.

Pendapatan yang diperoleh petani dari usahatani cabai merupakan selisih antara penerimaan dengan total biaya usahatani cabai yang dikeluarkan dalam satu kali musim tanam. Data pada Tabel 1, menunjukkan bahwa pendapatan atas biaya total yang diperoleh petani cabai besar yaitu Rp119.047.409,08/ha. Selanjutnya, pendapatan atasbiaya total yang diperoleh petani dari usahatani cabai rawit yaitu Rp49.579.540,49/ha. Nilai R/C atas biaya total pada usahatani cabai besar dan cabai rawit adalah 3,26 dan 1,75. Nilai $R / C>1$, maka usahatani cabai besar dan cabai rawit yang dilakukan oleh petani di Kecamatan Sumberejo menguntungkan untuk diusahakan.

Hasil penelitian ini sejalan dengan hasil penelitian yang dilakukan oleh Chonani, Prasmatiwi dan Santoso (2014) bahwa usahatani cabai merah merupakan usahatani yang menguntungkan dengan jumlah pendapatan usahatani cabai merah yaitu sebesar Rp56.202.114,24/ha. Selain itu, penelitian Agnes dan Antara (2017) menyatakan bahwa usahatani cabai rawit adalah usahatani yang menguntungkan dengan jumlah pendapatan dari usahatani cabai rawit yaitu Rp11.101.482,87/ha.

Uji beda dilakukan untuk membandingkan dua variabel dalam tempat dan waktu yang sama. Tabel 2 menunjukkan bahwa hasil analisis uji beda (independent sample $t$-test) dari penerimaan, biaya, dan pendapatan usahatani cabai besar dan cabai rawit diperoleh nilai sig.(2-tailed) $<0,05$ yang artinya terdapat perbedaan yang signifikan antara penerimaan, biaya, dan pendapatan usahatani cabai besar dan cabai rawit dengan tingkat kepercayaan 99 persen, dimana rata-rata penerimaan dan pendapatan usahatani cabai besar lebih tinggi dibandingkan dengan cabai rawit, sedangkan ratarata biaya usahatani cabai besar lebih rendah dibandingkan dengan cabai rawit.

Tabel 2. Perbandingan penerimaan, biaya, dan pendapatan usahatani cabai besar dan cabai rawit per hektar

\begin{tabular}{|c|c|c|c|c|}
\hline \multirow[b]{2}{*}{ Keterangan } & \multicolumn{2}{|c|}{ Usahatani } & \multirow[b]{2}{*}{$\begin{array}{c}\mathrm{t} \\
\text { hitung }\end{array}$} & \multirow[b]{2}{*}{ Sig. } \\
\hline & $\begin{array}{l}\text { Cabai besar } \\
\text { (Rp) }\end{array}$ & $\begin{array}{c}\text { Cabai rawit } \\
(\mathrm{Rp})\end{array}$ & & \\
\hline Penerimaan & 152.362 .966 & 112.403 .433 & 3,049 & $0,003 * * *$ \\
\hline Biaya & 61.016 .579 & 74.344 .418 & $-4,017$ & $0,000 * * *$ \\
\hline Pendapatan & 91.346 .387 & 38.059 .014 & . 3,816 & $0,000 * * *$ \\
\hline
\end{tabular}




\section{Risiko Usahatani Cabai}

Analisis risiko usahatani cabai dihitung dengan menggunakan data produksi dan harga cabai pada lima musim tanam terakhir (mt, mt-1, mt-2, mt-3, mt-4). Berdasarkan Gambar 1, rata-rata produksi cabai besar dan cabai rawit tertinggi terdapat pada mt-4 yang berada pada rata-rata produksi sebesar $6.663,58 \mathrm{~kg} / \mathrm{ha}$ dan $6.783,00 \mathrm{~kg} / \mathrm{ha}$, sedangkan produksi terendah terdapat pada musim tanam saat ini (mt) yaitu pada rata-rata produksi 5.496,58 $\mathrm{kg} / \mathrm{ha}$ dan $5.860,00 \mathrm{~kg} / \mathrm{ha}$. Naik turunnya hasil produksi usahatani cabai besar dan cabai rawit disebabkan oleh risiko dalam kegiatan produksi. Petani cabai besar dan cabai rawit di daerah penelitian sebagian besar pernah mengalami kehilangan hasil panen mulai dari 30 persen hingga 60 persen akibat cuaca buruk dan hama penyakit yang menyerang tanaman cabai sehingga produksi yang dihasilkan berfluktuasi di waktu pemanenan.

Risiko harga terbentuk atas adanya ketidakpastian harga dalam fluktuasi harga cabai. Harga jual cabai dipengaruhi oleh banyak sedikitnya produksi cabai yang tersedia. Keseluruhan cabai besar dan cabai rawit di daerah penelitian dijual ke pengepul dan biasanya pengepul juga menentukan dasar harga dari harga pasar, sehingga harga berfluktasi di setiap waktu pemanenan. Seperti yang dapat dilihat pada Gambar 2, rata-rata harga cabai besar lebih tinggi dibandingkan dengan rata-rata harga cabai rawit, namun kedua harga cabai tersebut sama-sama berfluktuasi. Hal ini salah satunya dikarenakan permintaan pada cabai besar lebih banyak dari cabai rawit. Harga cabai besar dan cabai rawit tertinggi terdapat pada mt-1 yaitu sebesar Rp32.016,67/kg dan Rp22.866,67/kg, sedangkan harga terendah terdapat pada mt-4 yaitu pada harga Rp22.900,00/kg dan Rp19.200,00/kg. Menurut Anwarudin et al. (2015), faktor yang menyebabkan harga cabai berfluktuasi adalah permintaan dan penawaran. Fluktuasi harga cabai terjadi, terutama karena tingginya permintaan.

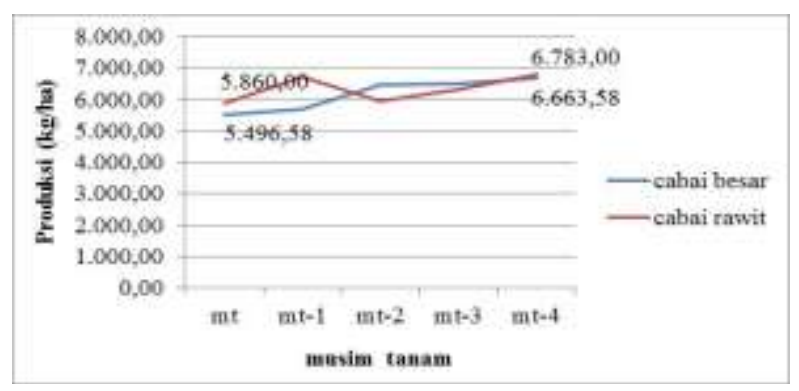

Gambar 1. Fluktuasi produksi cabai besar dan cabai rawit lima musim tanam terakhir

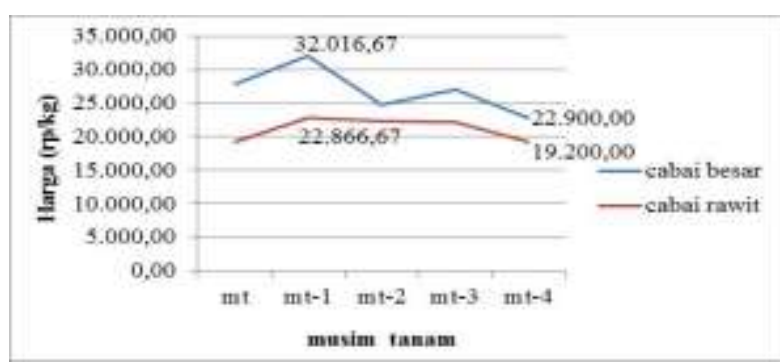

Gambar 2. Fluktuasi harga cabai besar dan cabai rawit lima musim tanam terakhir

Tingkat produksi dan harga menentukan tinggi rendahnya pendapatan cabai besar dan cabai rawit yang akan diterima petani. Pada Gambar 3, terlihat bahwa pendapatan usahatani cabai besar dan cabai rawit berfluktuasi, pendapatan cabai besar dan cabai rawit tertinggi terdapat pada mt-1 yaitu Rp110.863.542,59/ha dan Rp75.395.314,81/ha, dimana pada mt-1 produksi cabai besar dan cabai rawit di daerah penelitian selalu tersedia, karena masa panen cabai besar dan cabai rawit tidak secara serentak, sedangkan produksi dari luar daerah berkurang, sehingga harga jual cabai cukup tinggi dan pendapatan yang diterima petani juga tinggi. Selanjutnya, pendapatan usahatani cabai besar dan cabai rawit terendah terdapat pada $\mathrm{mt}$ Rp91.346.387,04/ha dan Rp38.059.014,81/ha.

Hal ini sejalan dengan penelitian yang dilakukan Nauly (2016) yang menyatakan bahwa tingginya harga cabai disebabkan oleh pasokan cabai yang berkurang, sementara permintaan konstan setiap hari bahkan meningkat pada musim tertentu. Menurut Anwarudin et al. (2015) mengemukakan bahwa tingkat harga yang tinggi umumnya terjadi saat pasokan cabai langka.

Nilai koefisien variasi menunjukkan peluang risiko produksi, harga, dan pendapatan yang dihadapi petani. Semakin tinggi nilai $\mathrm{CV}$ yang didapat, maka semakin besar risiko yang harus ditanggung petani (Pappas dan Hirschey 1995). Pada Tabel 3,

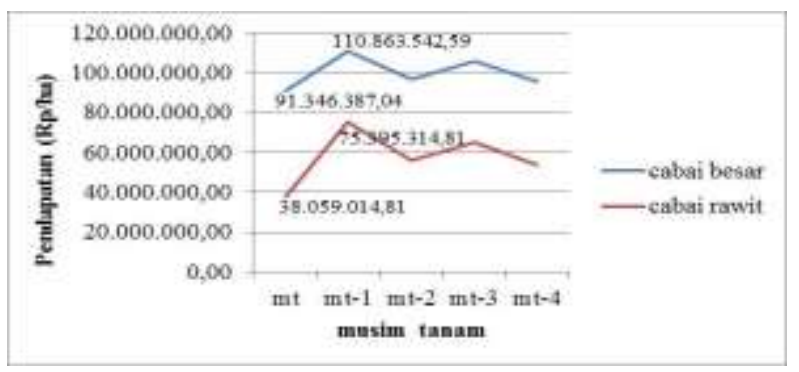

Gambar 3. Fluktuasi pendapatan cabai besar dan cabai rawit lima musim tanam terakhir 
terlihat risiko produksi dan harga memiliki nilai $\mathrm{CV}<0,50$ artinya risiko petani mengalami kerugian akibat perubahan produksi dan harga adalah rendah, sedangkan risiko pendapatan memiliki nilai $\mathrm{CV}>0,50$ yang artinya risiko petani mengalami kerugian akibat perubahan pendapatan adalah tinggi.

Hasil analisis uji beda risiko produksi usahatani cabai besar dan cabai rawit, diperoleh nilai sig.(2tailed) sebesar 0,461>0,05 artinya tidak terdapat perbedaan yang signifikan antara risiko produksi cabai besar dan cabai rawit. Kedua jenis cabai sama-sama sensitif terhadap perubahan cuaca dan rentan terhadap serangan hama dan penyakit yang berpengaruh pada pertumbuhan tanaman cabai.

Tanaman cabai besar dan cabai rawit merupakan salah satu tanaman yang sangat sensitif terhadap perubahan cuaca. Pengetahuan petani terhadap alternatif pemecahan masalah mengenai perubahan cuaca atau iklim yang berdampak pada usahatani cabai masih kurang, sehingga hal ini menjadi salah satu faktor penyebab terjadinya risiko produksi dalam usahatani cabai. Selain itu, keadaan cuaca yang tidak menentu menyebabkan tanaman cabai besar dan cabai rawit mudah terserang hama dan penyakit. Hama dan penyakit yang lebih banyak menyerang tanaman cabai besar dan cabai rawit dan sulit untuk dikendalikan oleh petani adalah thrips dan antraknosa. Hama dan penyakit tersebut dapat mengakibatkan kuantitas dan kualitas hasil panen cabai rendah. Untuk menghindari terjadinya gagal panen, para petani melakukan petik hijau pada tanaman cabai besar ketika hama penyakit menyerang tanaman cabai lebih dari 40 persen. Hal ini sejalan dengan penelitian Aini et al. (2015) yang mengemukakan bahwa risiko pada usahatani kubis disebabkan oleh cuaca dan hama penyakit.

Hasil analisis uji beda risiko harga cabai besar dan cabai rawit diperoleh nilai sig.(2-tailed) sebesar $0,000<0,05$ artinya terdapat perbedaan yang signifikan antara risiko harga cabai besar dan risiko harga cabai rawit dengan tingkat kepercayaan 99 persen, dimana risiko harga usahatani cabai besar lebih tinggi dibandingkan dengan risiko harga usahatani cabai rawit.

Selama lima musim tanam terakhir, fluktuasi harga cabai besar lebih tinggi dibandingkan cabai rawit, dengan harga cabai besar tertinggi yaitu sebesar Rp32.016,67/kg dan terendah Rp22.900,00/kg, sedangkan harga cabai rawit tertinggi yaitu $\mathrm{Rp} 22.866,67 / \mathrm{kg}$ dan terendah Rp19.200,00/kg.
Tabel 3. Perbandingan risiko produksi, harga dan pendapatan usahatani cabai besar dan cabai rawit per hektar

\begin{tabular}{|c|c|c|c|c|}
\hline \multirow[b]{2}{*}{ Uraian } & \multicolumn{2}{|c|}{ Usahatani } & \multirow[b]{2}{*}{$\begin{array}{c}\mathrm{t} \\
\text { hitung }\end{array}$} & \multirow[b]{2}{*}{ Sig. } \\
\hline & $\begin{array}{l}\text { Cabai } \\
\text { besar }\end{array}$ & $\begin{array}{c}\text { Cabai } \\
\text { rawit }\end{array}$ & & \\
\hline \multicolumn{5}{|l|}{ Risiko produksi } \\
\hline Koefisien variasi $(\mathrm{CV})$ & 0,28 & 0,26 & 0,743 & 0,461 \\
\hline \multicolumn{5}{|l|}{ Risiko harga } \\
\hline Koefisien variasi $(\mathrm{CV})$ & 0,41 & 0,26 & 5,715 & $0,000 * * *$ \\
\hline \multicolumn{5}{|l|}{ Risiko pendapatan } \\
\hline$\underline{\text { Koefisien variasi }(\mathrm{CV})}$ & 0,79 & 0,90 & $-0,926$ & 0,358 \\
\hline
\end{tabular}

Risiko harga cabai yang terlalu tinggi. dikarenakan permintaan terhadap cabai besar tetap banyak sedangkan produksi cabai berfluktuasi, sehingga berpengaruh terhadap besar kecilnya harga cabai besar yang diterima petani. Menurut Soekartawi, Rusmadi dan Damaijati (1993), ketidakpastian harga yang sulit diprediksi secara tepat, menyebabkan timbulnya fluktuasi harga. Faktorfaktor yang mempengaruhi yaitu adanya spekulasi pedagang yang cenderung ingin memperoleh keuntungan yang besar. Adanya ketidakpastian tersebut menimbulkan terjadinya risiko harga.

Hasil analisis uji beda risiko pendapatan usahatani cabai besar dan cabai rawit diperoleh nilai sig.(2tailed) sebesar 0,358>0,05 artinya tidak terdapat perbedaan yang signifikan antara risiko pendapatan cabai besar dan cabai rawit. Risiko pendapatan cabai besar dan cabai rawit sama-sama tinggi dengan fluktuasi pendapatan terendah adalah sebesar Rp91.346.387,04 dan Rp38.059.014,81. Nilai batas bawah (L) pendapatan usahatani cabai besar dan cabai rawit yang dihasilkan ialah sebesar -36.234.617,26 dan -28.019.371,14. Nilai batas bawah (L) < 0 yang artinya kemungkinan peluang kerugian pendapatan terendah yang diterima petani yaitu sebesar Rp-36.234.617,26 usahatani cabai besar dan Rp-28.019.371,14 usahatani cabai rawit. Untuk dapat meningkatkan pendapatan dan memperkecil peluang kerugian, sebaiknya petani tidak hanya menggantungkan pada usahatani cabai saja atau petani dapat menanam beberapa jenis tanaman pada lahan yang sama seperti dalam satu luas lahan ditanami cabai dengan tomat.

Risiko pendapatan usahatani cabai besar dan cabai rawit terbentuk atas adanya jumlah produksi cabai yang berfluktuasi dan harga jual cabai yang tidak stabil. Hal tersebut dipengaruhi oleh keadaan cuaca yang tidak menentu menyebabkan tanaman cabai mudah terserang hama penyakit, sehingga kuantitas dan kualitas hasil panen cabai besar dan 
cabai rawit rendah. Produksi cabai yang berfluktuasi berpengaruh terhadap besar kecilnya harga cabai besar dan cabai rawit yang diterima petani. Adanya ketidakpastian harga menimbulkan terjadinya risiko harga. Hal ini sejalan dengan penelitian Aini et al. (2015) menyatakan bahwa banyak sedikitnya produksi kubis yang tersedia akan mempengaruhi harga jual yang diterima petani. Hal ini, berlaku hukum penawaran, dimana semakin banyak barang yang ditawarkan maka harga semakin rendah, begitu pula sebaliknya.

\section{KESIMPULAN}

Pendapatan usahatani cabai besar lebih tinggi dibandingkan pendapatan usahatani cabai rawit di Kecamatan Sumberejo Kabupaten Tanggamus dengan jumlah pendapatan yang didapatkan oleh petani cabai besar yaitu Rp119.047.409,08/ha dan pendapatan usahatani cabai rawit ialah sebesar Rp49.579.540,49/ha. Tidak terdapat perbedaan yang signifikan antara risiko produksi dan risiko pendapatan usahatani cabai besar dan cabai rawit. Risiko harga usahatani cabai besar lebih tinggi dibandingkan dengan cabai rawit.

\section{DAFTAR PUSTAKA}

Agnes A dan Antara M. 2017. Analisis pendapatan dan kelayakan usahatani cabai rawit di Desa Sunju Kecamatan Marawola Kabupaten Segi. e-Jurnal Agrotekbis, 5 (1): 86-91. http://jurnal.untad.ac.id/jurnal/index.php/Agro tekbis/article/view/8906. [28 September 2019].

Aini NH, Prasmatiwi FE, dan Sayekti WD. 2015. Analisis pendapatan dan risiko usahatani kubis pada lahan kering dan lahan sawah tadah hujan di Kecamatan Gisting Kabupaten Tanggamus. Jurnal Ilmu Ilmu Agribisnis, 3(1): $\quad$ 1-9. http://jurnal.fp.unila.ac.id/index.php/JIA/articl e/view/1011. [03 November 2017].

Anwarudin MJ, Sayekti AL, Aditia MK, dan Yusdar. 2015. Dinamika produksi dan volatilitas harga cabai. Pengembangan Inovasi Pertanian, 8(1): 33-42. http://ejurnal

.litbang.pertanian.go.id/index.php/pip/article/view/ 2376. [28 September 2019].

Arifin Z. 2012. Penelitian Pendidikan Metode dan Paradigma Baru. Remaja Rosda Karya. Bandung.

Arikunto S. 2006. Prosedur Penelitian Suatu Pendekatan Praktik. Edisi Revisi VI. Rineka Cipta. Jakarta.
BPS [Badan Pusat Statistik]. 2019. Laju Pertumbuhan Sektor Pertanian Terhadap Produk Domestik Bruto Tahun 2018. https://www.bps.go.id/ [28 September 2019]

BPS [Badan Pusat Statistik] Kabupaten Tanggamus. 2017. Luas Panen dan Produksi Cabai Menurut Kecamatan di Kabupaten Tanggamus Tahun 2016. BPS Kabupaten Tanggamus. Kota Agung.

Chonani SH, Prasmatiwi FE, dan Santoso H. 2014. Efisiensi produksi dan pendapatan usahatani cabai merah di Kecamatan Metro Kibang Kabupaten Lampung Timur. Jurnal Ilmu Ilmu Agribisnis, 2(2): 95-102. http://jurnal.fp.unila.ac.id/index.php/ JIA/article/view/730. [15 Februari 2018].

Dinas Pertanian Tanaman Pangan dan Hortikultura Provinsi Lampung. 2017. Data Luas Panen, Produktivitas, dan Harga Cabai Besar dan Cabai Rawit. Dinas Pertanian Tanaman Pangan dan Hortikultura Provinsi Lampung. Bandar Lampung.

Gay LR dan Diehl PL. 1992. Research Methods for Business and Management. Mac Millan Publishing Company. New York.

Kadarsan HW. 1995. Keuangan Pertanian dan Pembiayaan Perusahaan Agribisnis. Gramedia Pustaka Utama. Jakarta.

Nauly D. 2016. Fluktuasi dan diparitas harga cabai di Indonesia. Jurnal Agrosains dan Teknologi, 1(1): 56-69. https://jurnal.umj.ac.

id/index.php/ftan/article/view/1479. [28 September 2019].

Pappas JL dan Hierschey M. 1995. Ekonomi Managerial Edisi Keenam Jilid II. Binarupa Aksara. Jakarta.

Prajnanta F. 2001. Agribisnis Cabai Hibrida. Penebar Swadaya. Jakarta.

Saputra JE, Prasmatiwi FE, dan Ismono RH. 2017. Pendapatan dan risiko usahatani jahe di Kecamatan Penengahan Kabupaten Lampung Selatan. Jurnal Ilmu Ilmu Agribisnis, 5(4): 392-398.

http://jurnal.fp.unila.ac.id/index.php/JIA/issue /view/159. [24 Juli 2019].

Setiadi. 2000. Bertanam Cabai. Penebar Swadaya. Jakarta.

Soekartawi, Rusmadi, dan Damaijati E. 1993. Risiko dan Ketidakpastian dalam Agribisnis. PT Raja Grafindo Persada. Jakarta.

Soekartawi. 1995. Analisis Usahatani. Raja Grafindo Persada. Jakarta.

Sugiarto, Siagian D, Sunaryanto LT, dan Oetomo DS. 2003. Teknik Sampling. PT Gramedia Pustaka Utama. Jakarta. 